rather than at the east end as proposed. The chancellor found that the relative inconvenience of locating the font near the principal entrance, where it would limit the flexibility of the welcome area, did not amount to circumstances out of the ordinary. However, the fact that a tradition had developed within the church of baptisms taking place at the front of the church did amount to circumstances out of the ordinary justifying an alternative location. The faculty was granted. [RA]

doi:10.1017/So956618X1200110X

\title{
Re St Paul, Herne Hill
}

Southwark Consistory Court: Petchey Ch, 4 September 2012 War memorial

The petitioners sought a faculty for the creation of a welcome area at the west end of the church. The proposals involved the removal of the rood screen, on which had been included a First World War memorial, to the west end of the church, to be incorporated within the partition that separated the new welcome area from the main body of the church. The chancellor had sought the advice of the War Memorials Trust, who did not support the screen being moved. The chancellor stated that he had greater reservations about authorising the moving of a screen that was a war memorial than one that was not. In this case, the memorial would be moved further from the high altar, but the chancellor was satisfied that it would have greater prominence in its new position and that this outweighed any disadvantage in moving it. The faculty was granted. [RA] 